\title{
Intraguild predation between the invasive ladybird Harmonia axyridis and non-target European coccinellid species
}

\author{
Angelos Katsanis • Dirk Babendreier • \\ Wolfgang Nentwig • Marc Kenis
}

Received: 4 March 2011/Accepted: 29 June 2012/Published online: 19 August 2012

(C) International Organization for Biological Control (IOBC) 2012

\begin{abstract}
The coccinellid Harmonia axyridis (Pallas) has been used for augmentative and classical biological control in many environments. More recently it has invaded large parts of Europe and negative effects for native populations of aphidophagous coccinellids are beginning to emerge. Here we investigate intraguild predation (IGP) between $H$. axyridis and eleven native non-target European coccinellids, including less common species which have not been studied so far within this context of non-target effects. When first-instars of $H$. axyridis were paired with the native species, only Anatis ocellata (Linnaeus) and Calvia quatuordecimguttata (L.) were significantly superior to the former whereas $H$. axyridis was superior in three cases, i.e. against Aphidecta obliterata (L.), Coccinella septempunctata L. and Hippodamia variegata (Goeze). Non-
\end{abstract}

Handling Editor: Arne Janssen

A. Katsanis - D. Babendreier · M. Kenis

CABI Europe-Switzerland, Rue des Grillons 1, 2800 Delémont, Switzerland

A. Katsanis $(\bowtie)$

Department of Ecology and Evolution,

University of Lausanne, UNIL Sorge, Le Biophore,

1015 Lausanne, Switzerland

e-mail: angelos.katsanis@unil.ch

W. Nentwig

Community Ecology, Institute of Ecology and Evolution, University of Bern, Baltzerstrasse 6, 3012 Bern,

Switzerland significant results were obtained for all other pairings. Similar tests with the fourth larval instar revealed stronger IGP rates and $H$. axyridis was found to be superior in the interactions with Adalia bipunctata (L.), Adalia decempunctata (L.), A. obliterata, Calvia decemguttata (L.), C. quatuordecimguttata, C. septempunctata, $H$. variegata, Oenopia conglobata (L.) and Propylea quatuordecimpunctata (L.) whereas nonsignificant results were obtained for interactions with two other native species. Another experiment revealed that $H$. axyridis was able to prey more successfully upon egg of most native coccinellid species than vice versa. However, C. quatuordecimguttata eggs seem to be more protected against predation than those of the other species. Survival of first-instar $H$. axyridis was higher on conspecific eggs compared to eggs of any other species tested. Our results suggest that $H$. axyridis may become a threat to a wide range of native aphidophagous coccinellids sharing similar ecological niches except species showing high potential for chemical or physical protection.

Keywords Invasive species - Harmonia axyridis . Intraguild predation $\cdot$ Coccinellidae .

Impact on biodiversity

\section{Introduction}

The introduction of exotic natural enemies to control pest species in the framework of a biological control project 
involves potential risks to native species (Babendreier 2007; De Clercq et al. 2011). Biological control is viewed as an environmentally benign alternative to chemical control. When successful, it leads to long-term reduction in pest numbers and damage (van Lenteren 2008; van Driesche et al. 2010). However, the intentional release of biological control agents is also seen as a threat to the structure and dynamics of biological communities. The introduction of biological control agents can have potential harmful effects on indigenous species, which could potentially lead to species extinction (Howarth 1991; Simberloff 1992). In particular, generalist predators, if maintained at high densities on common alternative hosts can potentially drive a rare non-target species to extinction (Howarth 1991).

One of the mechanisms leading to non-target effects in exotic generalist predators is intraguild predation (IGP), which is defined as the predation between two species that share a host or prey (Polis et al. 1989). IGP can be asymmetrical, in which case one species consistently preys upon the other, or symmetrical, when both species prey equally upon each other (Polis et al. 1989). IGP is generally recognised to influence interactions between multiple predators and their control effects on prey (Rosenheim et al. 1993; Snyder 2009). IGP among predators can be intense, resulting in high mortality of the intraguild prey, while the additional mortality imposed upon the shared prey population may be minimal. IGP can sometimes lead to the breakdown of biological control (Vance-Chalcraft et al. 2007) but Janssen et al. (2006) showed that, in most cases, IGP does not disrupt biological control.

The harlequin ladybird Harmonia axyridis (Pallas) (Coleoptera: Coccinellidae) is a predator that is often involved in IGP, in most cases with aphid predators (Pell et al. 2008), but also with parasitoids and entomopathogens (Roy et al. 2008; Meisner et al. 2011). This beetle originates from Asia and its native distribution extends from the Altai Mountains in the west to the Pacific Coast in the east, and from southern Siberia in the north to southern China in the south (Koch 2003). It is a multivoltine species, found in many different habitats, such as broadleaved forests and urban trees, orchards and various agricultural crops, where it feeds mainly on aphids. However, it feeds also on other homopterans such as coccids (McClure 1986), juvenile psyllids (Michaud 2002), and even other herbivorous arthropods such as mites (Lucas et al. 1997), a chrysomelid used as a weed biological control agent (Sebolt and Landis 2004), weevil larvae (Kalaskar and Evans 2001) and the eggs and larvae of the monarch butterfly (Koch 2003). The larvae and adults are very voracious and can be easily reared, which makes the species a very efficient biological control agent against aphids (Koch 2003). It was repeatedly released as a biological control agent in North America since 1916 (Gordon 1985; McClure 1987) but only became firmly established in 1988 (Chapin and Brou 1991). Now, it is found across most of North America. In Europe, it was first released in Ukraine in 1964 (Katsoyannos et al. 1997) and more extensively used and marketed in several countries in the 1990s, mainly for augmentative biological control in greenhouses and orchards (Brown et al. 2008). H. axyridis' establishment was first reported in 1999 in Germany and it has been spreading throughout Europe ever since. It is now present in more than 20 European countries, where it has quickly become one of the most abundant ladybird species (Brown et al. 2008; Roy et al. 2012).

Among other consequences, the invasion of $H$. axyridis may have a serious impact on native biodiversity, in particular aphidophagous ladybirds, through competition for food and direct predation (Pell et al. 2008). Local displacement of native ladybirds has already been observed in agricultural habitats in North America (Colunga-Garcia and Gage 1998; Michaud 2002) and, very recently, in various habitats and regions in Europe (Roy et al. 2012).

Dixon (2000) has shown that, in aphidophagous coccinellid guilds, IGP is most likely to occur between immature stages, including predation of eggs by larvae. Recent laboratory studies (Ware and Majerus 2008; Ware et al. 2008a) have examined IGP between $H$. axyridis and aphidophagous coccinellid species and provided evidence that $H$. axyridis larvae are often superior to larvae of other ladybird species in laboratory conditions. Other laboratory studies (Cottrell 2004; Ware et al. 2008b) have further reported on predation of native European and North American coccinellid species eggs by $H$. axyridis larvae and adults. Cannibalism is a common phenomenon in coccinellids and the nutritional benefits that a larva can gain from consuming a conspecific egg can be substantial (Snyder et al. 2000). Since different ladybird species often oviposit simultaneously on the same patches, a larva can potentially also consume eggs or larvae of any other encountered species. Thus, there is increasing evidence for a risk that $H$. axyridis can successfully displace native European 
coccinellids, as has also been shown in recent field studies conducted in several European countries (Roy et al. 2012). One limiting factor of those studies on IGP and potential environmental risks of the invasion of $H$. axyridis is that, until now, most of them focused on few ladybird species, mainly the most common ones. The most complete studies in IGP between $H$. axyridis and European ladybirds were those by Ware and Majerus (2008), who described IGP tests between larvae, prepupae and pupae of eight European species, and Ware et al. (2008a), who tested predation on eggs of six of these species. However, over 100 species of coccinellids are described in Europe, from which there is basically no information available regarding the outcome of IGP. Adriaens et al. (2008) and Kenis et al. (2010) showed that H. axyridis has a high degree of niche overlap with native European coccinellid, mostly aphidophagous, species. In addition, previous studies (Hautier et al. 2008, 2011) revealed high levels of IGP on field-collected native coccinellids. All aphidophagous coccinellids distribute themselves contagiously according to the distribution of aphids, thereby increasing encounter probability and, subsequently, IGP probability (Lucas 2005). Therefore, it seems that aphidophagous species are more likely to encounter $H$. axyridis in the field, which could lead to a possible interaction between the invasive and the native species (Kenis et al. 2010).

In this study, we aimed to determine the outcome of these interactions by testing the IGP between $H$. axyridis and 11 native European coccinellid species at the first and fourth larval instar as well as predation levels of the eggs of the native European coccinellid species by firstinstar $H$. axyridis larvae, and vice versa. In addition, the nutritional benefits of consuming a conspecific or an interspecific egg by a $H$. axyridis larva were determined though survival experiments. We focused exclusively on aphidophagous species and particularly included less common species associated with broadleaved woody plants, such as Calvia decemguttata (Linnaeus) and Oenopia conglobata (L.), since it is also the preferred habitat of $H$. axyridis (Adriaens et al. 2008).

\section{Materials and methods}

\section{Coccinellid cultures}

The mean adult size (in mm, from the top of the head to the end of the elytra, mean of ten adults from laboratory rearing) and the classification of defensive larval spines (according to Savoiskaya and Klausnitzer 1973) are shown in parenthesis for each coccinellid species used in this study: Adalia bipunctata (Linnaeus) (4.4/not spiny), Adalia decempunctata (L.) (3.9/not spiny), Anatis ocellata (L.) (7.0/very spiny), Aphidecta obliterata (L.) (4.1/not spiny), C. decemguttata (L.) (4.3/not spiny), Calvia quatuordecimguttata (L.) (4.4/spiny), Coccinella septempunctata L. (6.4/not spiny), H. axyridis (Pallas) (6.5/very spiny), Hippodamia undecimnotata (Schneider) (5.6/spiny), Hippodamia variegata (L.) (4.0/not spiny), O. conglobata (L.) (4.0/not spiny) and Propylea quatuordecempunctata (L.) (3.6/not spiny). All are native European species, except $H$. axyridis. Details on the biology and habitat preference of the native species can be found in Majerus (1994) and Klausnitzer and Klausnitzer (1997). All individuals used in experiments were F1 or F2 offspring from samples of coccinellid adults collected in various areas in Switzerland. Species with more than ten adults available were housed in $28 \times 28 \times 28 \mathrm{~cm}$ cages lined with filter paper, while species for which a smaller number of individuals was available were kept in $9 \mathrm{~cm}$ diameter Petri dishes, also lined with filter paper. The cages contained potted pea plants infested with an excess number of pea aphids, Acyrthosiphon pisum (Harris), a species known to be accepted as prey by most aphidophagous ladybirds and which was used successfully by Ware and Majerus (2008) and Ware et al. (2008a) in their studies on IGP between $H$. axyridis and various European and Asian ladybirds. Cages, filter papers and infested pea plants were changed every four days, or even at shorter intervals when plants were withered. Egg batches found on the filter paper were removed from the cages by cutting the paper around them with fine scissors. Ladybird eggs that were found on the shoots of the pea plants were also removed by cutting these shoots. Coccinellid eggs that were attached on the pea plant pots or on the cage walls were carefully detached with a fine brush sterilised with $97 \%$ alcohol. Adults bred in Petri dishes were fed with an excess of pea aphids changed every two days. Eggs were collected from the filter paper and the Petri dish walls in the same way. All eggs that were removed from cages or Petri dishes were placed in $9 \mathrm{~cm}$ Petri dishes lined with filter paper for eclosion. Larvae were provided with an excess of aphids, changed every two days. All ladybird stages 
were maintained under constant environment conditions at $20{ }^{\circ} \mathrm{C}$ and $16 \mathrm{hL} / 8 \mathrm{hD}$. The same conditions were used for all experiments described below.

\section{IGP between larvae}

IGP experiments were done between first-instars and between fourth (last) instars to allow a comparison with the results obtained by Ware and Majerus (2008) who used the same instars of the same and other ladybird species. Newly hatched larvae of $H$. axyridis and native European coccinellid species were given an excess of pea aphids for $24 \mathrm{~h}$. A single 1-day old $H$. axyridis larva was transferred to one side of a clean $3 \mathrm{~cm}$ Petri dish using a sterilised fine paint brush. A single 1-day old larva of an indigenous species or of $H$. axyridis was then added to the opposite side of the Petri dish. No other resource was provided thereafter. The outcome of the interaction between the two individuals was noted $24 \mathrm{~h}$ after the start of the experiment: no IGP, i.e. no larva was eaten; IGP in favour of $H$. axyridis, i.e. when a larva from a native coccinellid species was eaten by $H$. axyridis; and IGP in favour of the native species, i.e. when a larva of $H$. axyridis was eaten by the larva of a native coccinellid species. The observation was done under a stereo microscope to distinguish the larvae and to confirm IGP from any evidence of injury. The experiments were replicated 30 times for each of the 12 ladybird species tested.

In a second experiment, fourth-instar larvae were agematched according to the date of the third ecdysis. The larvae were starved $24 \mathrm{~h}$ prior to the experiments. A single fourth-instar $H$. axyridis larva was transferred to one side of a clean $3 \mathrm{~cm}$ Petri dish using a sterilised fine paintbrush. A single fourth-instar larva of an indigenous species, or of $H$. axyridis, was then added to the opposite side of the Petri dish. No other food or water was provided thereafter. For all interactions, observation times, prey status and replicates were as mentioned above.

IGP on eggs by first-instar larvae

One individual first-instar larva and one egg were introduced simultaneously in $3 \mathrm{~cm}$ diameter Petri dishes. No other resource was provided thereafter. After $24 \mathrm{~h}$ the 'status' of the egg was observed under the stereo microscope and scored into one of three categories as in Ware et al. (2008a): not eaten, when the egg was completely untouched; partially eaten, when the chorion was broken but at least $1 / 3$ of yolk remained; and completely eaten, when the whole egg had been consumed or less than $1 / 3$ of the yolk remained at the poles (Ware et al. 2008a). The egg was then removed and the larva was kept under the same conditions until death and monitored three times a day at 8:00, 13:00 and 18:00. Because all experiments started at the same time of the day (13:00), this regular monitoring allowed us to calculate and compare the approximate survival time of the larvae of the different species. First-instar larvae of $H$. axyridis were tested with eggs of the 11 European species and $H$. axyridis. Similarly, first-instar larvae of the nine European species were tested against an egg of $H$. axyridis. A. ocellata and A. obliterata were not tested in this experiment. Every combination was replicated 30 times. For each combination, egg palatability and egg susceptibility were calculated. Palatability was defined as the number of eggs completely eaten and susceptibility was defined as the number of eggs partially or completely eaten.

\section{Statistical analysis}

The symmetry of IGP between $H$. axyridis and the indigenous ladybird species at first and fourth larval instar was analysed by using the binomial test, the null hypothesis being that predation is equally likely to occur in both ways. Analysis of the palatability of the eggs was done in $2 \times 2$ contingency tables using $\chi^{2}$ tests by comparing the number of the eggs that were falling in the categories 'Not eaten' and 'Partially eaten' versus the category 'Completely eaten'. The analysis of the egg susceptibility was done in $2 \times 2$ contingency tables using $\chi^{2}$ tests by comparing the number of the eggs that fell into the category 'Not eaten' versus the categories 'Partially eaten' and 'Completely eaten'. In all cases, whenever an expected value was less than 5, the Fisher's exact test was used. Kaplan-Meier analyses were performed with larval survival data and comparisons were made by using log-rank tests. All statistics were performed using the SPSS v18.0 programme.

\section{Results}

IGP between larvae

In IGP experiments between first-instar larvae of $H$. axyridis and native European coccinellid species, 
predation was observed in less than $50 \%$ of the replicates, except when $H$. axyridis was tested against A. ocellata, A. obliterata and $H$. undecimnotata (Fig. 1). IGP was significantly asymmetric in favour of $H$. axyridis in combinations with A. obliterata, $C$. septempunctata and $H$. undecimnotata larvae. In contrast, IGP was asymmetric in favour of the native species in tests with A. ocellata and C. quatuordecimguttata. No significant asymmetry was observed in the six other combinations. Predation rarely occurred between $H$. axyridis larvae.

In IGP experiments between fourth-instar larvae, rates of predation above $60 \%$ for all combinations were observed, except when $H$. axyridis larvae were tested against conspecific larvae (Fig. 2). IGP was significantly asymmetric in favour of $H$. axyridis in most combinations. In no combination was IGP asymmetric in favour of the native species while tests between $H$. axyridis larvae and A. ocellata and $H$. undecimnotata larvae did not provide significant asymmetry.

IGP on eggs by first-instar larvae

First-instar $H$. axyridis larvae were able to prey upon the eggs of all native species. The species most susceptible to IGP by $H$. axyridis were A. bipunctata,
A. decempunctata, A. obliterata, $C$. decemguttata, $C$. septempunctata, $H$. variegata, $O$. conglobata and $H$. axyridis itself (Fig. 3). Over $90 \%$ of the eggs of these species were attacked by first-instar $H$. axyridis larvae. However, H. axyridis eggs were also highly susceptible to predation by native species. Egg susceptibility was significantly asymmetric in favour of $H$. axyridis only in the combination with $O$. conglobata $\left(\chi^{2}=12.0, d f=1, n=60, p<0.001\right)$ but not in the other combinations. In contrast, only $40 \%$ of the C. quatuordecimguttata eggs were attacked by $H$. axyridis first-instar larvae and egg susceptibility was significantly asymmetric in favour of this native species $\left(\chi^{2}=7.20, \quad d f=1, \quad n=60, \quad p=0.007\right)$ (Fig. 3).

The coccinellid eggs were considered palatable when at least $2 / 3$ of the total mass of the egg was consumed by the coccinellid larva. Over $80 \%$ of the eggs of A. bipunctata, A. decempunctata, A. obliterata, C. septempunctata, O. conglobata, P. quatuordecempunctata and $H$. axyridis were completely consumed by first-instar $H$. axyridis larvae (Fig. 3). On the other hand, only $3.3 \%$ of the eggs of $C$. quatuordecimguttata were completely consumed by H. axyridis larvae. Egg palatability comparisons between the number of native coccinellid eggs preyed by $H$. axyridis first-instar larvae and vice versa showed

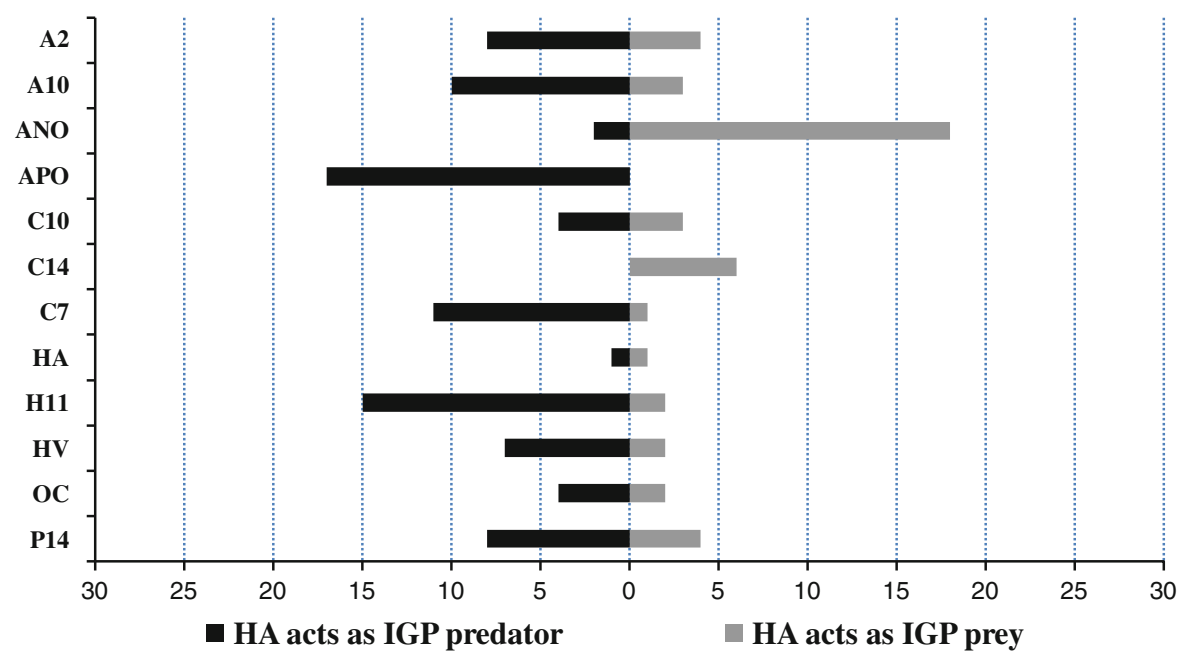

Fig. 1 Symmetry of IGP between $H$. axyridis and European coccinellids at the first larval instar. $\mathrm{n}=30$. Bars indicate the number of replicates falling into each category: left bars $H$. axyridis acts as an intraguild predator, right bars $H$. axyridis acts an intraguild prey. Abbreviations indicate the species tested: A2 Adalia bipunctata, A10 Adalia decempunctata,
ANO Anatis ocellata, APO Aphidecta obliterata, C10 Calvia decemguttata, $\mathrm{C} 14$ Calvia quatuordecimguttata, C7 Coccinella septempunctata, HA Harmonia axyridis, H11 Hippodamia undecimnotata, HV Hippodamia variegata, OC Oenopia conglobata, P14 Propylea quatuordecempunctata 
Fig. 2 Symmetry of IGP between $H$. axyridis and European coccinellids at the fourth larval instar. $n=30$. Bars indicate the number of replicates falling into each category: left bars $H$. axyridis acts as an intraguild predator, right bars $H$. axyridis acts an intraguild prey. Species abbreviations are mentioned in Fig. 1

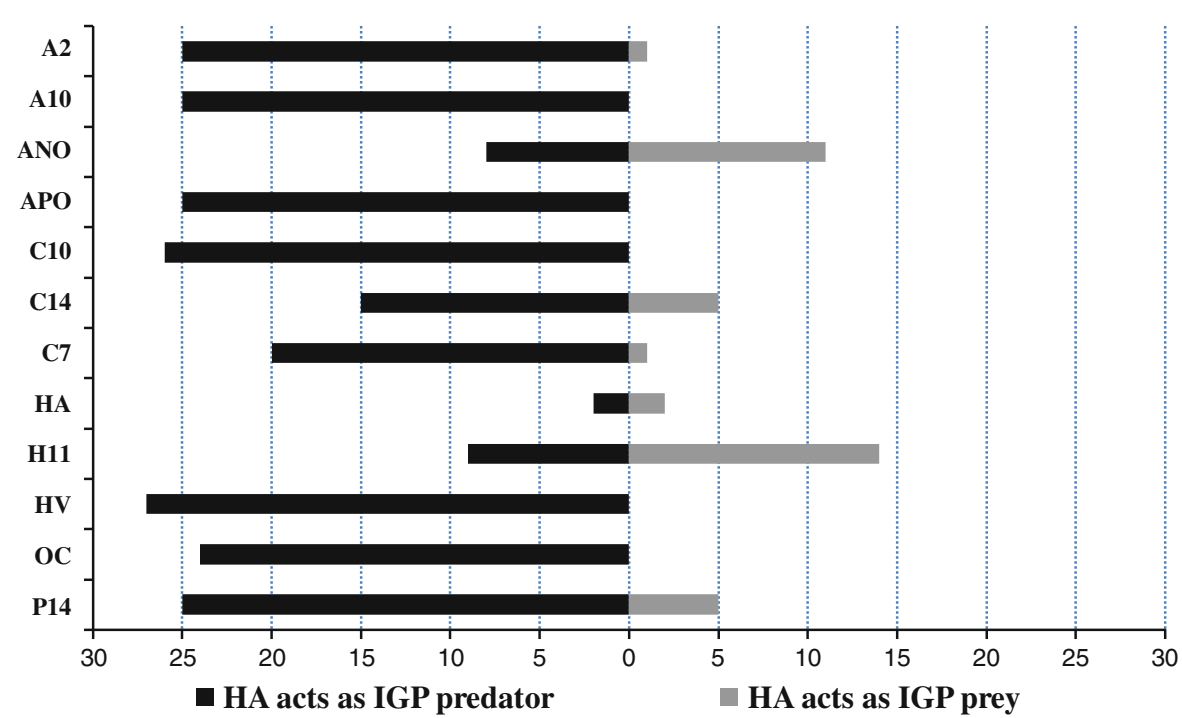

Survival of first-instar $H$. axyridis larvae after predation on coccinellid eggs

Survival of first-instar $H$. axyridis differed significantly depending on which eggs they preyed upon, regardless of whether the no-egg control was included $\left(\log -\right.$ rank test: $\chi^{2}=397.2, \quad d f=12, \quad \mathrm{n}=357$, $p<0.001$, Fig. 4) or excluded from statistical analysis $\left(\chi^{2}=184.1, d f=11, \mathrm{n}=327, p<0.001\right.$, Fig. 4). Post-hoc tests showed that survival of first-instar $H$. axyridis larvae was significantly increased when they
Fig. 3 Symmetry of IGP on eggs by first-instar larvae $(\mathrm{n}=30$ for every combination). Bars indicate the number of replicates falling into each category: black bars completely eaten eggs, grey bars partially eaten eggs, left bars predation of native species eggs by $H$. axyridis larvae, right bars predation of $H$. axyridis eggs by native and conspecific larvae. Species abbreviations are mentioned in Fig. 1

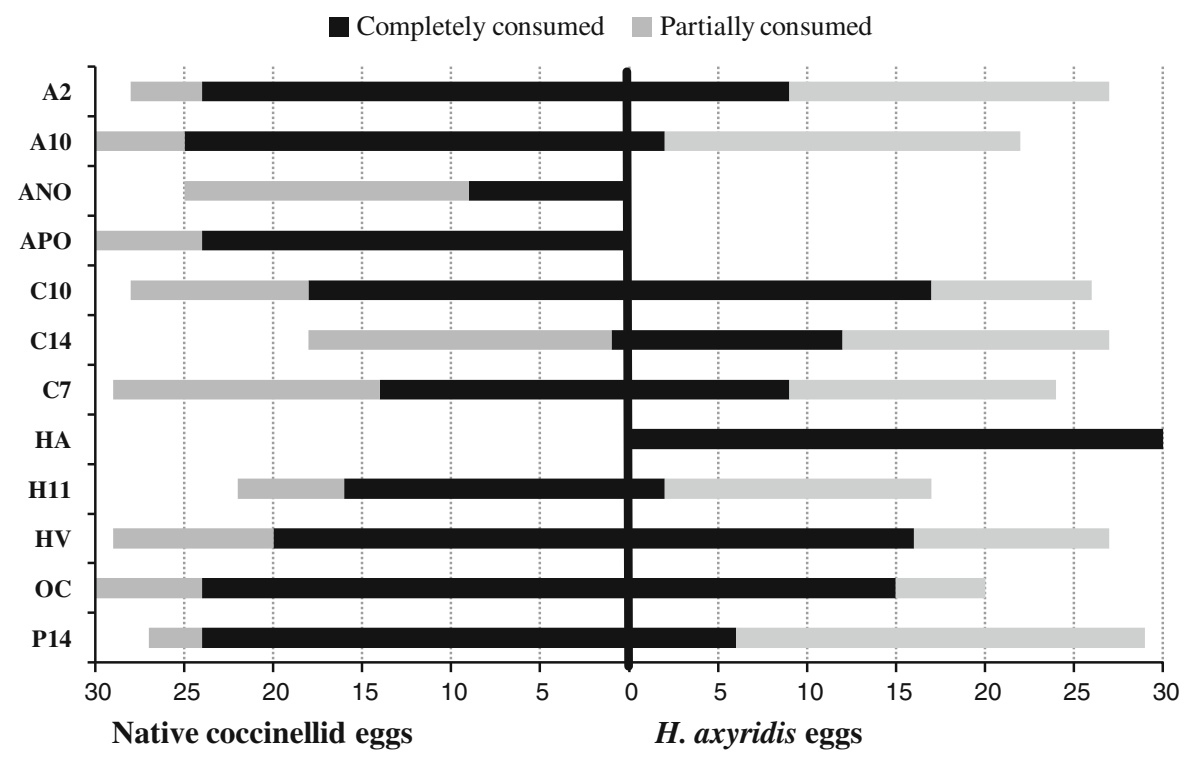


fed on conspecific eggs compared to eggs from all other tested coccinellid species (log-rank tests, $d f=1, p<0.001$, Fig. 4). However, first-instar $H$. axyridis larvae also profited from feeding on heterospecific eggs as survival was significantly increased, compared to the no-egg control, when preying upon eggs of any of the native species (log-rank tests, $d f=1, p \leq 0.001$, Fig. 4).

\section{Discussion}

IGP tests between larvae showed that $H$. axyridis is an asymmetric predator of most indigenous ladybirds, particularly in the last instar. Six of the 11 indigenous species tested in this study had already been tested against $H$. axyridis larvae under similar conditions by Ware and Majerus (2008). Our results are in line with the results of their study, with $A$. ocellata acting as intraguild predator, Adalia spp., C. septempunctata and $P$. quatuordecimpunctata acting as intraguild prey.

Factors that may determine the issue of IGP between larvae in Petri dishes are the respective size of the larvae and the presence of defensive spines. According to Félix and Soares (2004), the result of IGP between larvae is influenced by the relative size of the species involved with the larger species often taking a leading role and acting as intraguild predator rather that intraguild prey, which the smaller species is forced to become. Larval sizes for the 12 tested species are not provided here, nor anywhere in the literature, but the relative size of larvae is strongly linked to that of the adults, particularly in the last instar (Katsanis personal observation). Size differences are much less pronounced in first-instar larvae than in last instar larvae, which may partly explain the lower IGP rate observed among first-instars. In the field, $H$. axyridis and the native species are not necessarily at the same stage when they encounter each other. Therefore, it is probable that young $H$. axyridis larvae may become prey of later instar larvae of native coccinellids. A. ocellata, which lives in conifer habitats, is the only European species clearly bigger at all stages than $H$. axyridis. It is also the only species that did not act as intraguild prey in any of the two larval stages tested. However, other large species, such as C. septempunctata did not show any resistance against attacks by

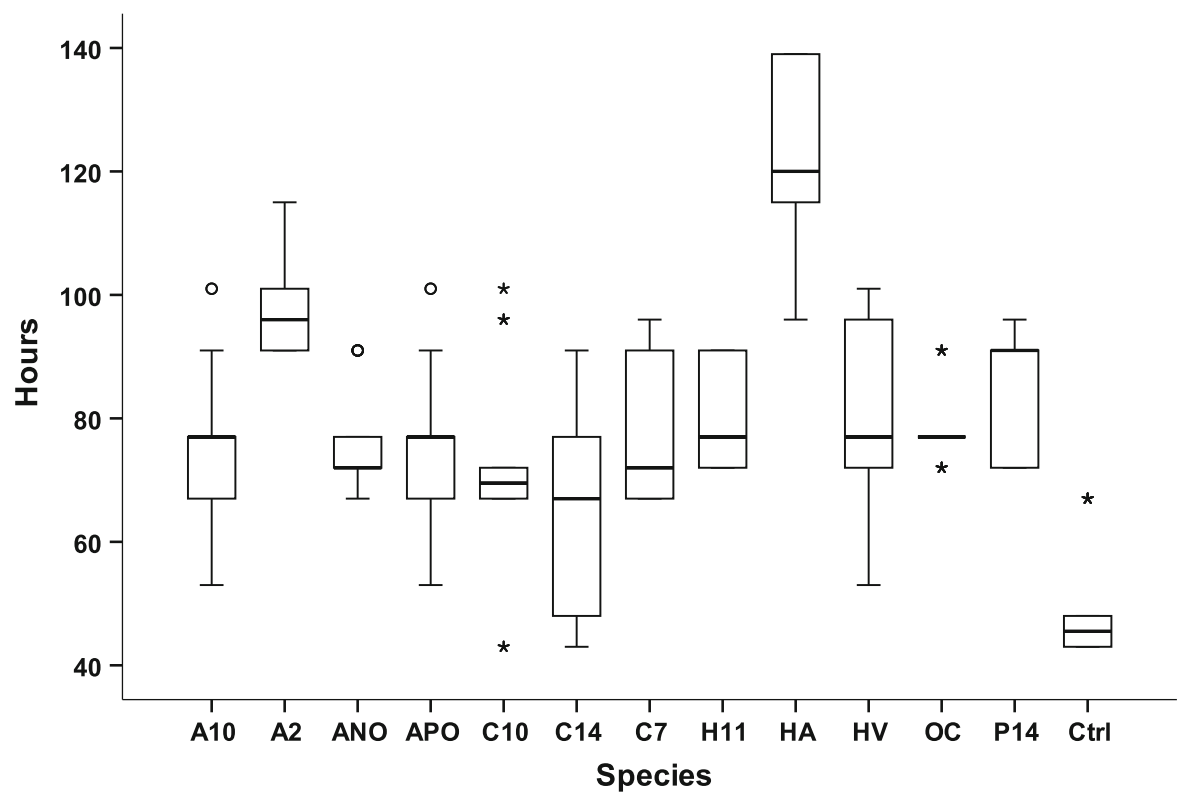

Fig. 4 Survival time of first-instar larvae of $H$. axyridis after consuming either a conspecific egg or an egg of a European coccinellid species. Medians, interquartile ranges, outliers and extremes are shown. The circles above bars indicate the outliers, defined as values between 1.5 and 3 interquartile ranges above the upper, or below the lower, edge of the interquartile range, and stars above and below the bars indicate values more than three interquartile ranges above the upper, or below the lower, edge of the interquartile range. Species abbreviations are mentioned in Fig. 1. 'Ctrl' indicates the control experiment where no coccinellid eggs were given to larvae of $H$. axyridis 
$H$. axyridis and acted as intraguild prey, perhaps because larvae lack the protective dorsal spines. Spines have often been cited as a means to protect ladybird larvae from predation (Michaud and Grant 2003; Ware et al. 2008a). In our study, small species without larval spines, e.g. A. obliterata, P. quatuordecimpunctata, $C$. decemguttata, O. conglobata, $H$. variegata and Adalia spp., were clearly the most vulnerable. Hardly any cannibalism occurred between $H$. axyridis larvae, in contrast to what was observed by Michaud (2003). Some other European coccinellid species share this characteristic, in particular species of the Chilocorinae subfamily, e.g. Chilocorus renipustulatus or Exochomus quadripustulatus, which, to our knowledge, were never tested in IGP experiments against $H$. axyridis.

Eggs of most indigenous species were more susceptible and palatable to $H$. axyridis larvae than eggs of $H$. axyridis were to larvae of the indigenous species, except for eggs of $C$. quatuordecimguttata, which were not eaten by $H$. axyridis larvae. In contrast, eggs of the congeneric species $C$. decemguttata were heavily preyed upon by $H$. axyridis. Insect eggs are often chemically protected against generalist predators (Blum and Hilker 2002), which, in ladybirds, can be due to species-specific alkaloids and other compounds on the surface or inside the eggs. These compounds are also present throughout the whole life cycle of the coccinellids (Pasteels et al. 1973; Hemptinne and Dixon 2000). Hemptinne et al. (2000) listed the compounds found in the egg surface of $A$. bipunctata and $C$. septempunctata, which may be used to avoid cannibalism and IGP by coccinellid larvae. In addition, Ware et al. (2008b) have shown that the eggs of $C$. quatuordecimguttata are protected by chemical deterrents that are found on the egg surface of the eggs. These mainly consist of a mixture of hydrocarbons in combination with an unidentified substance that is believed to belong to the acid group. As Hemptinne et al. (2000) suggest, unpalatability and toxicity of coccinellid eggs should be advertised by a chemical signal on the egg's surface. It seems that this could be the case with the eggs of $C$. quatuordecimguttata, a species that also occurs in East Asia (Fauna Europaea 2012) and, thus, co-evolved with H. axyridis. However, in species with clustered eggs, such a signal may not be needed since the intraguild predator will experience the unpalatability when consuming the first egg it encounters. Further research is needed to identify the exact compounds that repel the larvae of H. axyridis.

The analysis of the survival times showed, as mentioned also in Ware et al. (2008b), that feeding $H$. axyridis larvae with a coccinellid egg did not reduce survival below that of a starved larva. Although $H$. axyridis larvae are capable of completing development on interspecific eggs, this results in prolonged development and lower adult weight (Cottrell 2004). The consumption of European coccinellid eggs by first-instar $H$. axyridis larvae resulted also in a reduction of survival in comparison to the consumption of a conspecific egg. Previous studies (Agarwala and Dixon 1991; Michaud 2002; Omkar Pervez and Gupta 2006) with no-choice and choice experiments have shown that coccinellid larvae tend to prefer preying on conspecific eggs rather than heterospecific ones, perhaps because of the presence of specific surface alkanes, and/or alkaloids in the conspecific eggs (Hemptinne et al. 2000). Ware et al. (2008b) also tested the palatability and susceptibility of five European species and $H$. axyridis by $H$. axyridis larvae-but not the reverse-and obtained similar results, conspecific $H$. axyridis eggs being the most palatable and susceptible and those of $C$. quatuordecimguttata being the least palatable and susceptible. Cannibalism of sibling eggs by hatching larvae is considered adaptive in aphidophagous guilds due to the mass and survival increases it can confer (Osawa 1992; Snyder et al. 2000), and H. axyridis is not an exception. The benefits of egg cannibalism on ladybirds, including $H$. axyridis, have been well studied and include various components of fitness, such as larger size, competitive advantage in mating, higher fecundity, faster development and earlier maturity (Ueno et al. 1998; Osawa 1992; Michaud and Grant 2004). Other studies have shown that $H$. axyridis eggs are toxic and unpalatable to larvae of other species (Cottrell 2004; Sato and Dixon 2004). This, together with the asymmetric IGP observed in the larval stage (this study) and in the pre-pupal and pupal stages (Ware and Majerus 2008) confers a serious competitive advantage for the invasive species compared to native ladybird that may partly explain its tremendous invasion success in Europe and North America and may lead to the decline of the most susceptible species.

IGP is not the only mechanism through which $H$. axyridis can affect populations of native ladybirds. Competition for resources alone can also lead to the 
displacement of native coccinellid species that share the same prey and habitat as $H$. axyridis (Harmon et al. 2007). Alyokhin and Sewell (2004) and Evans (2004) provided evidence that the invasion of $H$. axyridis and C. septempunctata were followed by a significant decline in aphid densities in agricultural fields, which, in turn, resulted in local declines in native ladybirds. In his review, Snyder (2009) showed that increases in predator species richness in communities that include coccinellids have generally resulted in increased prey suppression. According to Snyder (2009), IGP between ladybirds is rarely a strongly disruptive force, possibly because spatiotemporal niche differences reduce encounters among species. However, this is not the case in all systems. Adding a generalist predator into a predator-prey system may release prey populations from regulation by their main predator, as observed by Rosenheim et al. (1993) in the aphid Aphis gossypii-Chrysoperla carnea system.

It must be noted that our experiments were done in small, confined arenas. IGP is usually less severe in the presence of the shared prey (Polis et al. 1989) and, thus, laboratory experiments where no other food source is available probably overestimate the incidence of IGP between species. Furthermore, habitat structure seems to lead to reduction of IGP (Janssen et al. 2007). Although recent studies based on the analyses of exogenous alkaloids in field-collected $H$. axyridis showed that $H$. axyridis regularly feeds on some native European ladybirds in the field (Hautier et al. 2008, 2011), little is known regarding the extent of IGP on most native ladybirds. In nature, many ladybird species have adopted strategies to prevent IGP by other ladybird species, either by avoiding oviposition on plants with fresh larval tracks of IG predators (Doumbia et al. 1998), by co-occurring in the field with the intraguild predator as older, less vulnerable stage (Sato and Dixon 2004) or by adopting behavioural strategies that provide immediate escape, such as high mobility of larvae and dropping off the plant when a predator approaches (Lucas et al. 1997; Sato et al. 2005). Avoidance strategies and their effect on IGP should be studies in larger environments such as field cages.

Acknowledgments The authors wish to acknowledge the help of Mr. Johan van Vlaenderen for assistance in collecting coccinellids and in laboratory work. We are grateful to Dr. Christelle Péré, Ms. Natalia Guazzone, Mr. Ioan-Sorin Sirbu and Ms. Luma Delaplace for assistance in maintaining the cultures of aphids and coccinellids. We are also thankful to the late Dr. Mike Majerus and Dr. Remy Poland for helpful discussions and to Mr. Louis Hautier for providing us cultures of aphids. We thank the anonymous reviewers for their very helpful comments on the manuscript. This study was funded by the Swiss National Science Foundation (Grant 3100A0-117831/1).

\section{References}

Adriaens T, San Martin y Gomez G, Maes D (2008) Invasion history, habitat preferences and phenology of the invasive ladybird Harmonia axyridis in Belgium. BioControl 53: 69-88

Agarwala BK, Dixon AFG (1991) Cannibalism and interspecific predation in ladybirds. In: Pogar L, Chambers R, Dixon AFG, Hodek I (eds) Behaviour and impact of aphidophaga. SPB Academic Publishers, The Hague, The Netherlands, pp $95-102$

Alyokhin A, Sewell G (2004) Changes in a lady beetle community following the establishment of three alien species. Biol Invasions 6:463-471

Babendreier D (2007) Pros and cons of biological control. In: Nentwig W (ed) Biological invasions. Springer, Berlin, Germany, pp 403-418

Blum MS, Hilker M (2002) Chemical protection of insect eggs. In: Hilker M, Meiners T (eds) Chemoecology of insect eggs and egg deposition. Blackwell, Berlin, Germany, pp 61-90

Brown PMJ, Adriaens T, Bathon H, Cuppen J, Goldarazena A, Hägg T, Kenis M, Klausnitzer BE, Kovar I, Loomans AJ, Majerus MEN, Nedved O, Pedersen J, Rabitsch W, Roy HE, Ternois V, Zakharov I, Roy DB (2008) Harmonia axyridis in Europe: spread and distribution of a non-native coccinellid. BioControl 53:5-21

Chapin JB, Brou VA (1991) Harmonia axyridis (Pallas), the third species of the genus to be found in the United States (Coleoptera: Coccinellidae). Proc Entomol Soc Wash 93: 630-635

Colunga-Garcia M, Gage SH (1998) Arrival, establishment, and habitat use of the multicolored Asian lady beetle (Coleoptera: Coccinellidae) in a Michigan landscape. Environ Entomol 27:1574-1580

Cottrell TE (2004) Suitability of exotic and native lady beetle eggs (Coleoptera: Coccinellidae) for development of lady beetle larvae. Biol Control 31:362-371

De Clercq P, Mason PG, Babendreier D (2011) Benefits and risks of exotic biological control agents. BioControl 56: 681-698

Dixon AFG (2000) Insect predator-prey dynamics: ladybird beetles and biological control. Cambridge University Press, Cambridge, UK

Doumbia M, Hemptinne JL, Dixon AFG (1998) Assessment of patch quality by ladybirds: role of larval tracks. Oecologia 113:197-202

Evans EW (2004) Habitat displacement of North American ladybirds by an introduced species. Ecology 85:637-647

Fauna Europaea (2012) Fauna Europaea version 2.4. http:// www.faunaeur.org. Accessed 28 May 2012

Félix S, Soares AO (2004) Intraguild predation between the aphidophagous ladybird beetles Harmonia axyridis and 
Coccinella undecimpunctata (Coleoptera: Coccinellidae): the role of body weight. Eur J Entomol 101:237-242

Gordon RD (1985) The Coleoptera (Coccinellidae) of America north of Mexico. J N Y Entomol Soc 93:1-912

Harmon JP, Stephens E, Losey J (2007) The decline of native coccinellids (Coleoptera: Coccinellidae) in the United States and Canada. J Insect Conserv 11:85-94

Hautier L, Grégoire JC, de Schauwers J, San Martin G, Callier P, Jansen JP, de Biseau JC (2008) Intraguild predation by Harmonia axyridis on coccinellids revealed by exogenous alkaloid sequestration. Chemoecology 18:191-196

Hautier L, San Martin y Gomez G, Callier P, de Biseau J, Gregoire J (2011) Alkaloids provide evidence of intraguild predation on native coccinellids by Harmonia axyridis in the field. Biol Invasions 13:1805-1814

Hemptinne JL, Dixon AFG (2000) Defence, oviposition and sex: semiochemical parsimony in two species of ladybird beetles (Coleoptera, Coccinellidae)? A short review. Eur J Entomol 97:443-447

Hemptinne JL, Lognay G, Gauthier C, Dixon AFG (2000) Role of surface chemical signals in egg cannibalism and intraguild predation in ladybirds (Coleoptera: Coccinellidae). Chemoecology 10:123-128

Howarth FG (1991) Environmental impacts of classical biological control. Annu Rev Entomol 36:485-509

Janssen A, Montserrat M, HilleRisLambers R, de Roos AM, Pallini A, Sabelis MW (2006) Intraguild predation usually does not disrupt biological control. In: Brodeur J, Boivin G (eds) Trophic and guild interactions in biological control, vol 3. Springer, Dordrecht, The Netherlands, pp 21-44

Janssen A, Sabelis MW, Magalhães S, Montserrat M, van der Hammen T (2007) Habitat structure affects intraguild predation. Ecology 88:2713-2719

Kalaskar A, Evans EW (2001) Larval responses of aphidophagous ladybeetles (Coleoptera: Coccinellidae) to weevil larvae versus aphids as prey. Ann Entomol Soc Am 94:76-81

Katsoyannos P, Kontodimas DC, Stathas GJ, Tsartsalis CT (1997) Establishment of Harmonia axyridis on citrus and some data on its phenology in Greece. Phytoparasitica 25:183-191

Kenis M, Adriaens T, Brown P, Katsanis A, van Vlaenderen J, Eschen R, Golaz L, Zindel R, San Martin y Gomez G, Babendreier D, Ware R (2010) Impact of Harmonia axyridis on European ladybirds: Which species are most at risk? IOBC/WPRS Bull 58:57-59

Klausnitzer B, Klausnitzer H (1997) Marienkäfer. Neue BrehmBücherei, Magdeburg, Germany

Koch RL (2003) The multicoloured Asian lady beetle, Harmonia axyridis: a review of its biology, uses in biological control and non-target impacts. J Insect Sci 3:1-16

Lucas E (2005) Intraguild predation among aphidophagous predators. Eur J Entomol 102:351-364

Lucas E, Coderre D, Vincent C (1997) Voracity and feeding preferences of two aphidophagous coccinellids on Aphis citricola and Tetranychus urticae. Entomol Exp Appl 85:151-159

Majerus MEN (1994) Ladybirds (No. 81, new naturalist series). HarperCollins, London, UK

McClure MS (1986) Role of predators in regulation of endemic populations of Matsucoccus matsumarae (Homoptera: Margarodidae) in Japan. Environ Entomol 15:976-983
McClure MS (1987) Potential of the Asian predator, Harmonia axyridis Pallas (Coleoptera: Coccinellidae), to control Matsucoccus resinosae Bean and Godwin (Homoptera: Margarodidae) in the United States. Environ Entomol $16: 224-230$

Meisner M, Harmon JP, Harvey CT, Ives AR (2011) Intraguild predation on the parasitoid Aphidius ervi by the generalist predator Harmonia axyridis: the threat and its avoidance. Entomol Exp Appl 138:193-201

Michaud JP (2002) Invasion of the Florida citrus ecosystem by Harmonia axyridis (Coleoptera: Coccinellidae) and asymmetric competition with a native species, Cycloneda sanguinea. Environ Entomol 31:827-835

Michaud JP (2003) A comparative study of larval cannibalism in three species of ladybeetle (Coleoptera: Coccinellidae). Ecol Entomol 28:92-101

Michaud JP, Grant AK (2003) Intraguild predation among ladybeetles and a green lacewing: Do the larval spines of Curinus coeruleus (Coleoptera: Coccinellidae) serve a defensive function? Bull Entomol Res 93:499-505

Michaud JP, Grant AK (2004) The adaptive significance of sibling egg cannibalism in the Coccinellidae: comparative evidence from three species. Ann Entomol Soc Am 97: 710-719

Omkar Pervez A, Gupta K (2006) Why do neonates of aphidophagous ladybird beetles preferentially consume conspecific eggs in presence of aphids? Biocontrol Sci Technol 16:233-243

Osawa N (1992) Sibling cannibalism in the ladybird beetle Harmonia axyridis Pallas: fitness consequences for mother and offspring. Res Popul Ecol 34:45-55

Pasteels JM, Deroe C, Tursch B, Braekman JC, Daloze D, Hootele C (1973) Distribution et activités des alcaloïdes défensifs des Coccinellidae. J Insect Physiol 19:1771-1784

Pell JK, Baverstock J, Roy HE, Ware RL, Majerus MEN (2008) Intraguild predation involving Harmonia axyridis: a review of current knowledge and future perspectives. BioControl 53:147-168

Polis GA, Myers CA, Holt RD (1989) The ecology and evolution of intraguild predation: potential competitors that eat each other. Annu Rev Ecol Syst 20:297-330

Rosenheim JA, Wilhoit LR, Armer CA (1993) Influence of intraguild predation among insect predators on the suppression of a herbivore population. Oecologia 96:439-449

Roy HE, Baverstock J, Ware RL, Clark SJ, Majerus MEN, Baverstock KE, Pell JK (2008) Intraguild predation of the aphid pathogenic fungus Pandora neoaphidis by the invasive coccinellid Harmonia axyridis. Ecol Entomol 33:1-8

Roy HE, Adriaens T, Isaac NJB, Kenis M, Onkelinx T, San Martin G, Brown PMJ, Hautier L, Poland R, Roy DB, Comont R, Eschen R, Frost R, Zindel R, van Vlaenderen J, Nedvěd O, Ravn HP, Grégoire J-C, de Biseau J-C, Maes D (2012) Invasive alien predator causes rapid declines of native European ladybirds. Divers Distrib 18:717-725

Sato S, Dixon AFG (2004) Effect of intraguild predation on the survival and development of tree species of aphidophagous ladybirds: consequences for invasive species. Agric For Entomol 6:21-24

Sato S, Yasuda H, Evans EW (2005) Dropping behaviour of larvae of aphidophagous ladybirds and its effect on 
incidence of intraguild predation: interactions between the intraguild prey, Adalia bipunctata (L.) and Coccinella septempunctata (L.), and the intraguild predator, Harmonia axyridis Pallas. Ecol Entomol 30:220-224

Savoiskaya GI, Klausnitzer B (1973) In: Hodek I (ed) Biology of Coccinellidae. Academia Publishing House of the Czechoslovak Academy of Sciences, Prague, Czech Republic, pp 36-55

Sebolt DC, Landis DA (2004) Arthropod predators of Galerucella calmariensis L. (Coleoptera: Chrysomelidae): an assessment of biotic interference. Environ Entomol 33:356-361

Simberloff D (1992) Conservation of pristine habitats and unintended effects of biological control. In: Kaufmann WC, Nechols JE (eds) Selection criteria and ecological consequences of importing natural enemies. ESA, Lanham, USA, pp 103-117

Snyder WE (2009) Coccinellids in diverse communities: Which niche fits? Biol Control 51:323-335

Snyder WE, Joseph SB, Preziosi RF, Moore AJ (2000) Nutritional benefits of cannibalism for the lady beetle Harmonia axyridis (Coleoptera: Coccinellidae) when prey quality is poor. Environ Entomol 29:1173-1179

Ueno H, Sato Y, Tsuchida K (1998) Colour-associated mating success in a polymorphic ladybird beetle, Harmonia axyridis. Funct Ecol 12:757-761

van Driesche RG, Carruthers RI, Center T, Hoddle MS, HoughGoldstein J, Morin L, Smith L, Wagner DL, Blossey B, Brancatini V, Casagrande R, Causton CE, Coetzee JA, Cuda J, Ding J, Fowler SV, Frank JH, Fuester R, Goolsby J, Grodowitz M, Heard TA, Hil MP, Hoffmann JH, Huber J, Julien M, Kairo MTK, Kenis M, Mason P, Medal J, Messing R, Miller R, Moore A, Neuenschwander P, Newman R, Norambuena H, Palmer WA, Pemberton R, Perez Panduro A, Pratt PD, Rayamajhi M, Salom S, Sands D, Schooler S, Sheppard A, Shaw R, Schwarzländer M, Tipping PW, van Klinken RD (2010) Classical biological control for the protection of natural ecosystems: past achievements and current efforts. Biol Control 54:S2-S33

van Lenteren JC (ed) (2008) IOBC Internet book of biological control. http://www.iobc-global.org/download/IOBC\% 20InternetBookBiCoVersion5January2008.pdf. Accessed 28 May 2012

Vance-Chalcraft HD, Rosenheim JA, Vonesh JR, Osenberg WC, Sih A (2007) The influence of intraguild predation on aphid suppression and prey release: a meta-analysis. Ecology 88:2689-2696

Ware RL, Majerus MEN (2008) Intraguild predation of immature stages of British and Japanese coccinellids by the invasive ladybird Harmonia axyridis. BioControl 53: 169-188

Ware RL, Evans N, Malpas L, Michie LJ, O'Farrell K, Majerus MEN (2008a) Intraguild predation of British and Japanese coccinellid eggs by the invasive ladybird Harmonia axyridis. Neobiota 7:263-275

Ware RL, Ramon-Portugal F, Magro A, Ducamp C, Hemptinne JL, Majerus MEN (2008b) Chemical protection of Calvia quatuordecimguttata eggs against intraguild predation by the invasive ladybird Harmonia axyridis. BioControl 53:189-200

\section{Author Biographies}

Angelos Katsanis performed this research as a part of his $\mathrm{PhD}$ project which was devoted to the investigation of the interactions between the invasive Asian multicoloured ladybeetle, Harmonia axyridis, and non-target European coccinellid and lepidopteran species. Currently, Dr. Katsanis works as an ecological entomologist at the University of Lausanne, Switzerland with focus on plant-insect interactions.

Dirk Babendreier is an Ecological Entomologist and Integrated Crop Management Advisor at CABI Europe-Switzerland with focus on risk assessment of classical and inundative biological control agents.

Wolfgang Nentwig is the Head of the Community Ecology Division in the Institute of Ecology and Evolution at the University of Bern, Switzerland. His focus is on the biological control of pests and weeds and the ecology of invasive species, transgenic plants and the agricultural landscape.

Marc Kenis is the Head of the Department of Risk Analysis and Invasion Ecology at CABI Europe-Switzerland with vast experience on the ecology and management of invasive species and other insect pests. 